\title{
Micronutrient Assessment of Cocoa, Kola, Cashew and Coffee Plantations for Sustainable Production at Uhonmora, Edo State, Nigeria
}

\author{
Joseph Sunday Ogeh ${ }^{1}$ and Rotimi Rofus Ipinmoroti ${ }^{2}$ \\ ${ }^{1}$ Department of Soil Science, Faculty of Agriculture, University of Benin, Benin City, Edo State 300001, \\ Nigeria, e-mail: joseph.ogeh@uniben.edu \\ ${ }^{2}$ Soil and Plant Nutrition Section, Cocoa Research Institute of Nigeria, P.M.B. 5244, Ibadan, Oyo State, \\ Nigeria, e-mail: ipinmoroti2r@ymail.com
}

Received 1 August 2012 / accepted 4 March 2013

\begin{abstract}
The micronutrient status of the soils and leaf of cocoa, kola, cashew and coffee plantations to study the soil-plant micronutrient content relationship in the plantation soils for proper management towards optimum production of the crops was investigated at Uhonmora, Edo State, Nigeria. Soil and leaf samples were collected from these plantations and analyzed according to standard laboratory procedures. The soil samples were analyzed for the micronutrients $(\mathrm{Cu}, \mathrm{Mn}, \mathrm{Zn}$ and $\mathrm{Fe}$ ) and in addition $\mathrm{pH}$, organic carbon, sand, silt and clay contents, while the leaves were analyzed for only the micronutrient contents. Results indicated that the soils were sandy loam, acidic, low in organic carbon, deficient in $\mathrm{Cu}$ and $\mathrm{Mn}$ but very high in $\mathrm{Fe}$ and $\mathrm{Zn}$ contents. This probably resulted in nutrient imbalance in the soils and the deficiency of the nutrients in the crops. The plantations therefore require application of organic manures and micronutrient fertilizers to rectify the inadequate soil organic matter and to supply sufficient amount of $\mathrm{Cu}$ and $\mathrm{Mn}$ in the soils, to obtain quality fruit yield at optimum level from the plantations.
\end{abstract}

Keywords: Cashew, cocoa, coffee, kola, micronutrients, sustainable production

\section{INTRODUCTION}

Micronutrients are essential chemical elements needed in small quantity for normal growth and development of crops (McKenzie 2001). When tree crops cannot get the micronutrients $(\mathrm{Zn}, \mathrm{Cu}, \mathrm{Mn}, \mathrm{B}$, $\mathrm{Fe}$ and $\mathrm{Cl}$ ) in the required amount or when their supply is not proportionally balanced, they do not grow or develop properly, and may slowly die. Cocoa (Thoebroma cacao), kola (Kola nitida), cashew (Anacadium occidentale) and coffee (Coffee arabica) are tree crops which are very sensitive to the quantity and proportion of supplied nutrients for growth and development. Nigerian farmers rarely apply fertilizers on their farms hence; crops depend on natural supply of nutrients and more importantly, micronutrients, which are supplied from the soil with no effort through fertilizer application (Iremiren and Ekhomun 2005).

Studies on cocoa, kola, cashew and coffee production and fertilizer usage over the years have been mainly on macronutrients with less emphasis on micronutrient needs of the crops (Omotosho

J Trop Soils, Vol. 18, No. 2, 2013: 93-97

ISSN 0852-257X
1974; Falade 1978; Ojeniyi 1980; Chude and Obigbesan 1983; Afolabi and Egbe 1984). Hence, information dissemination to farmers on fertilizer usage for plantation crops has been majorly on macronutrient elements with no micronutrient recommendation; while most of the farmers do not even apply the recommended fertilizers due to their scarcity and lack of purchasing power as a result of low income.

The contribution of cocoa, kola, cashew and coffee to Nigeria economy showed that cocoa

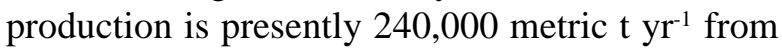
307,000 metric $\mathrm{y} \mathrm{yr}^{-1}$ (CBN 2010). Nigeria produces about 85,000 metric $\mathrm{t} \mathrm{yr}^{-1}$ of kola nuts compared to the previous figure of 127,000 metric $\mathrm{t} \mathrm{yr}^{-1}$ (Adebiyi et al.2011). Coffee production has declined to about

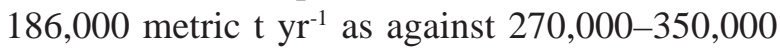

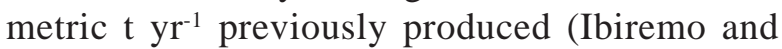
Fagbola 2008). Nigeria is the third largest producer of cashew nut in the world with a capacity of 850,000

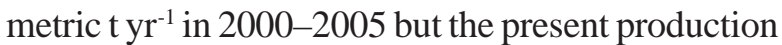
capacity of 660,000 metric $\mathrm{t} \mathrm{yr}^{-1}$ is reported by FAO (2010). This, however, indicates that production level is consistently on the decline.

Most of the plantations are over 50 years old and have become wasteful assets owing to old age, 
poor maintenance and lack of fertilizer application, severe pests and diseases attack as well as a combination of these factors (Ipinmoroti et al. 2009). Attempt to replant the plantations with improved seedlings have not been successful due to high soil $\mathrm{Cu}$ residue on cocoa plantations (Ayanlaja 1983), deficient and imbalanced soil nutrients (Ipinmoroti et al. 2011). It therefore shows that decline in soil fertility, imbalance use of fertilizer nutrients are subjects of concern towards solving low yield of the crops in most of the plantations in Nigeria. Nigerian soils lack of adequate plant nutrients and organic matter (Ogunwale et al. 2002). Hence, most of the tree crop plantations in Nigeria are established on medium to low fertility status soils (Egbe et al. 1989) with resultant low yield by farmers.

Improper fertilizer recommendation because of lack of adequate soil testing (Ogunlade et al. 2011) has resulted to imbalance supply of nutrients to crops. This study was therefore carried out to assess the micronutrient status of some old cocoa, coffee, cashew and kola plantations in Uhonmora area of Edo State, Nigeria for possibility of remedying deficiency and imbalance for optimal performance of the plantations.

\section{MATERIALS AND METHODS}

\section{Soil Preparation}

Ten soil samples from 2 ha area each from the cocoa, kola, cashew and coffee plantations were collected at 0-30 $\mathrm{cm}$ soil depth. These soil samples from each plantation were processed and uniformly mixed to form a composite sample per plantation. Indicator leaf samples, fourth matured leaf from the tip of the plant branches, were collected from four cocoa, kola, cashew and coffee trees which were very close to the point of soil sample collections. Leaf samples were oven-dried to constant weight at $70^{\circ} \mathrm{C}$ and milled using Hammar mill (ML 100).

\section{Soil Analysis}

The soil $\mathrm{pH}$ was determined in soil-water $(1: 2.5)$ suspension using the digital electronic $\mathrm{pH}$ meter, soil organic carbon was determined by the procedure of Walkley and Black by wet oxidation using chromic acid digestion (Nelson and Sommers 1982). The soil micronutients - $\mathrm{Cu}, \mathrm{Zn}, \mathrm{Mn}$ and $\mathrm{Fe}$ were determined after extraction of the soils with $0.1 \mathrm{~N} \mathrm{HCl}$ and the filtrate was read by use of PerkinElmer Atomic Absorption Spectrophotometer (AOAC 1990). The plant samples were ashed with Murphy furnace at $500{ }^{\circ} \mathrm{C}$ for 5 hours, cooled, dissolved with $5-\mathrm{mL}$ of $0.4 \mathrm{~N} \mathrm{HCl}$ and leached to 100-mL with distilled water. The filtrates were determined for the $\mathrm{Cu}, \mathrm{Zn}, \mathrm{Mn}$ and Fe contents by use of Perkin-Elmer Atomic Absorption Spectrophotometer. Micronutrient need was calculated based on individual element critical level and crop requirements, while the organic carbon needs were by direct calculation according to each plantation soil level.

\section{RESULTS AND DISCUSSION}

The particle size, organic carbon content and $\mathrm{pH}$ of the plantation soils are presented in Table 1. The plantation soils were generally sandy loam in texture. The sand fraction ranged from 754-818 g $\mathrm{kg}^{-1}$, the silt fraction from $9.6-13.1 \mathrm{~g} \mathrm{~kg}^{-1}$ and the clay fraction from $6.5-13.7 \mathrm{~g} \mathrm{~kg}^{-1}$. The organic carbon content ranged from $4.7-23.5 \mathrm{~g} \mathrm{~kg}^{-1}$. These were generally lower than $30 \mathrm{~g} \mathrm{~kg}^{-1}$ considered optimum for tree crop plantation (Egbe et al. 1989). The sandy nature of the soil and the very low level of organic carbon indicate that micronutrient supply, availability and uptake by crops will be difficult. This is because soils low in organic carbon (less than 20 $\mathrm{g} \mathrm{kg}^{-1}$ ) are prone to have lower micronutrient availability, while soils that are coarse textured (sandy soils) are more likely to be low in micronutrients (McKenzie 2001). The range of the soil $\mathrm{pH}$ was from 4.9-5.7 which indicated that they were acidic. This however, falls below 6.0-6.5 reported to be normal for tree cops like cocoa, coffee, cashew and kola (Opeke 1987). The soil $\mathrm{pH}$ will need to be corrected with the use of organic materials or liming materials or manures for optimal microbial activities in the soils and ease of

Table 1. Particle size of soil, textural class, organic carbon content and $\mathrm{pH}$ of the plantation soils.

\begin{tabular}{llrrlcc}
\hline Crop plantation & Sand & \multicolumn{1}{c}{ Silt } & Clay & Texture class & Organic carbon & $\mathrm{pH}$ \\
\hline & $\ldots \ldots \ldots \ldots \ldots \ldots . . \mathrm{g} \mathrm{kg}^{-1}$ & $\ldots \ldots \ldots \ldots \ldots \ldots \ldots \ldots \ldots \ldots$ & & & $\left(\mathrm{g} \mathrm{kg}^{-1}\right)$ & \\
Cocoa & 810 & 125 & 65 & Sandy loam & 5.3 & 5.7 \\
Cashew & 754 & 112 & 134 & Sandy loam & 9.3 & 5.7 \\
Kola & 762 & 131 & 107 & Sandy loam & 4.7 & 4.9 \\
Coffee & 818 & 96 & 86 & Sandy loam & 23.5 & 5.1 \\
\hline
\end{tabular}


macronutrient release for crop usage. This will also help to make sure that micronutrients are not released in a rate too much for normal crop growth and production performance.

The soil micronutrient content presented in Table 2 showed that the soils vary in the amount of $\mathrm{Zn}, \mathrm{Cu}, \mathrm{Fe}$ and $\mathrm{Mn}$ values in all the plantations. The $\mathrm{Cu}$ contents ranged from $0.39-2.57 \mathrm{mg} \mathrm{kg}^{-1}$ soil, with lower values in the kola and cocoa plantations compared to those of cashew and coffee plantation soils. The soil $\mathrm{Cu}$ level was only adequate for the coffee plantation, while it was below the soil critical level of $2.5 \mathrm{mg} \mathrm{kg}^{-1}$ (McKenzie 2001) for the cocoa, kola and cashew plantation soils. The Mn content in the cocoa plantation soil was 2.94 $\mathrm{mg} \mathrm{kg}^{-1}$. This was higher than that of kola, coffee and cashew plantations whose $\mathrm{Mn}$ content values ranged from $0.03-0.94 \mathrm{mg} \mathrm{kg}^{-1}$. When compared with soil critical level of $1.0 \mathrm{mg} \mathrm{kg}^{-1}$ (McKenzie 2001) the soil Mn content was adequate in the cocoa plantation, while it was generally deficient in the soils of the cashew, coffee and kola plantations.

The soil $\mathrm{Zn}$ content ranged from $30.1-54.2$ $\mathrm{mg} \mathrm{kg}{ }^{-1}$ as shown in Table 2. The values were generally higher than the soil critical value of $>1.0$ $\mathrm{mg} \mathrm{kg}^{-1}$ (McKenzie 2001).This indicates that the soil $\mathrm{Zn}$ content was adequate and would not be a source of nutritional problem in the plantations. The $\mathrm{Zn}$ level in the soil was similar for both coffee and cashew plots, which were significantly higher than values obtained from the cocoa and kola The

Table 2. Some micronutrient contents of the plantation soils.

\begin{tabular}{lcccc}
\hline $\begin{array}{l}\text { Crop } \\
\text { plantation }\end{array}$ & $\mathrm{Cu}$ & $\mathrm{Mn}$ & $\mathrm{Zn}$ & $\mathrm{Fe}$ \\
\hline & $\ldots \ldots \ldots \ldots \ldots \ldots \ldots . .$. & $\mathrm{mg} \mathrm{kg}^{-1}$ & soil $\ldots \ldots \ldots \ldots \ldots \ldots \ldots \ldots \ldots$ \\
Cocoa & 1.38 & 2.94 & 32.4 & 124 \\
Cashew & 1.94 & 0.94 & 53.6 & 232 \\
Kola & 0.39 & 0.03 & 30.1 & 198 \\
Coffee & 2.57 & 0.06 & 54.2 & 208 \\
\hline
\end{tabular}

Table 3. Leaf micronutrient contents for each crop.

\begin{tabular}{lcccc}
\hline $\begin{array}{l}\text { Crop } \\
\text { plantation }\end{array}$ & $\mathrm{Cu}$ & $\mathrm{Mn}$ & $\mathrm{Zn}$ & $\mathrm{Fe}$ \\
\hline & $\ldots \ldots \ldots \ldots \ldots \ldots \ldots \ldots \ldots . . \mathrm{mg} \mathrm{kg}^{-1}$ & $\ldots \ldots \ldots \ldots \ldots \ldots \ldots \ldots \ldots \ldots \ldots \ldots \ldots \ldots \ldots \ldots \ldots \ldots \ldots$ \\
Cocoa & 1.22 & 0.29 & 47.07 & 32.89 \\
Cashew & 2.08 & 0.58 & 8.89 & 23.33 \\
Kola & 2.11 & 0.15 & 20.92 & 27.85 \\
Coffee & 3.17 & 1.16 & 36.61 & 31.27 \\
\hline
\end{tabular}

plantations. The soil Fe content ranged from 124-32 $\mathrm{mg} \mathrm{kg}^{-1}$, with cashew plot having the highest value of $232 \mathrm{mg} \mathrm{kg}^{-1}$ while the least was recorded for the cocoa plot. However, the soil Fe contents were far above the critical value of $>4.5 \mathrm{mg} \mathrm{kg}^{-1}$ (McKenzie 2001) considered adequate for tree crops. Hence, the values were considered adequate and sufficient to meet the requirements for the plantation crops.

The leaf micronutrient contents are presented in Table 3. The crop leaf $\mathrm{Cu}$ content ranged from $1.22-3.17 \mathrm{mg} \mathrm{kg}^{-1}$ dry matter weight. The values were far below the critical level of $8.0 \mathrm{mg} \mathrm{kg}^{-1}$ dry weight (McKenzie 2001) considered sufficient for the tree crops. Similarly, the leaf Mn content were grossly found to be too low with a range from 0.29 $1.16 \mathrm{mg} \mathrm{kg}^{-1}$ dry weight, when compared with the values of $25.0 \mathrm{mg} \mathrm{kg}^{-1}$ dry weight (McKenzie 2001) calculated to be sufficient for tree crops. .The plant leaf contents of $\mathrm{Zn}$ in all the plantations ranged from $8.89-47.07 \mathrm{mg} \mathrm{kg}^{-1}$ dry weight. The value for the cashew plant was too low in the crop when compared to established critical level of $20 \mathrm{mg} \mathrm{kg}^{-1}$ dry weight (McKenzie 2001). It was marginal for kola, while it was considered to be sufficient for both the cocoa and coffee plants.

The plantation soils were coarse textured and very low in their organic carbon contents, which are common factors that make micronutrients not to be available for plant uptake in the soil (McKenzie 2001). The general trend of the soil micronutrient contents showed that the plantations soils were very low to marginal in their $\mathrm{Cu}$ and $\mathrm{Mn}$ levels. The soils could therefore not meet the required supply of the plantation crops for these nutrients. This is a clear indication that the crops would find it highly impossible to bear quality fruits at optimum levels. On the other hand, $\mathrm{Zn}$ and $\mathrm{Fe}$ which were found to be adequate in the plantation soils but not sufficiently supplied to the crops was an indication of nutrient imbalance in the soils. This indicates the situation of antagonistic reactions between the micronutrients in the soils. Hence, the micronutrients found to be adequate in the soil could not be sufficiently supplied to the crops. Therefore, production level from the plantation crops is expected to be low. Nutrient imbalance is a problem to crop development and productivity. It has been reported that high content of $\mathrm{Cu}, \mathrm{Fe}$ and $\mathrm{Mn}$ in the surface soil and low organic carbon lead to imbalance that courses constraints in getting good cocoa seedling establishment (Ayanlaja 1983). The situation in the plantations portrays the state of organic matter and micronutrient deficiency and nutrient imbalance which must be corrected. 
Table 4. Microutrient $\left(\mathrm{kg} \mathrm{ha}^{-1}\right)$ and manure $\left(\mathrm{tha}^{-1}\right)$ needs on the plantations.

\begin{tabular}{lccccc}
\hline Crop plantation & $\mathrm{Zn}$ & $\mathrm{Cu}$ & $\mathrm{Mn}$ & $\mathrm{Fe}$ & Manure \\
\hline Cocoa & - & 4.48 & - & - & 24.7 \\
Coffee & - & 2.24 & 0.24 & - & 20.7 \\
Kola & - & 8.44 & 3.88 & - & 25.3 \\
Cashew & - & - & 3.76 & - & 6.5 \\
\hline
\end{tabular}

micronutrient needs of the plantation to avert deficiency and optimum crop production are presented in Table 4. Based on the individual plot deficiency levels for organic matter and the micronutrients, the micronutrient need was calculated based on individual element critical level. The plantations would therefore need the application of $6.5-25.3 \mathrm{tha}^{-1}$ of manure so as to meet the organic carbon needs of the plantations. This will help to buffer the soils against the soil $\mathrm{pH}$ from becoming too acidic or alkaline. It will also serve as a secondary source of micronutrients upon decomposition and mineralization. Adequate manure in the soils will help to increase the soil CEC levels which were naturally low due to inherent low clay and organic matter contents of the tropical soils (Ogunwale et al. 2002).

The plantation soils would need application of 2.24-8.44 $\mathrm{kg} \mathrm{ha}^{-1}$ of $\mathrm{Cu}$ and $0.24-3.88 \mathrm{~kg} \mathrm{ha}^{-1}$ of $\mathrm{Mn}$, as copper sulphate and manganese sulphate respectively, in order to meet the deficient level of $\mathrm{Cu}$ and $\mathrm{Mn}$ of the plantations as shown in Table 4. The kola plantation had the highest amount of $\mathrm{Cu}$ and $\mathrm{Mn}$ requirement due to the very low level of the nutrients in the plantation soil. This might be due to excessive removal of the nutrients from the soil over the years through pod harvest which were not returned into the soils. The sufficiency of the plantation soils in $\mathrm{Zn}$ and $\mathrm{Fe}$ showed that the nutrients were not need to be applied to the plantations, while $\mathrm{Cu}$ and $\mathrm{Mn}$ fertilizers would not be needed in the coffee and cocoa plots respectively.

\section{CONCLUSIONS}

This investigation has been able to reveal the importance of micronutrient in the nutrition of these plantation crops. It was recorded that the plantation soils are very low in organic carbon, $\mathrm{Cu}$ and $\mathrm{Mn}$ contents but high in $\mathrm{Zn}$ and $\mathrm{Fe}$ contents, which must have lead to nutrient imbalance and deficient supply of the nutrients to the plantation crops. To correct the micronutrient imbalance on the plantations, suggestion therefore is that adequate auditing of the soil nutrients are needed to be carried out periodically. This can be at the end of every cropping season main harvest, in order to know the soil nutrient balance. Wherever insufficiency of any of these nutrients are observed and corrections are made appropriately in the next growing season to guide against low crop yield and poor quality harvest.

\section{ACKNOWLEDGEMENTS}

The authors acknowledged the Management of Cocoa Research Institute of Nigeria for permission to publish this work.

\section{REFERENCES}

Adebiyi S, EO Uwagbue, EA Agbongiarhuoyi, I Ndagi and EO Aigbekaen. 2011. Assessment of agronomic practices among kola farmers in Osun State, Nigeria. World JAgric Sci 7: 400-403.

Afolabi CA and NE Egbe. 1984. Yield response of kola to N, P and K fertilizer application: A case study of preliminary trial. Cafe Cacao The 28: 13-16.

AOAC [Association of Official Analytical Chemists]. 1990. Official Methods of Analysis, $15^{\text {th }}$ Edition. Washington DC: 774-784.

Ayanlaja SA. 1983. Rehabilitation of cocoa (Theobroma cacao L.) in Nigeria: Major problem and possible solution. Plant Soil 73: 403-409.

CBN [Central Bank of Nigeria]. 2010. Annual Report and Statement of Accounts for the year. Abuja, Nigeria. $182 \mathrm{p}$.

Chude VO and GO Obigbesan. 1983. Safe and toxic application rates of boron for cocoa seedlings. Plant Soil 74: 145-147.

Egbe NE, EA Ayodele and CR Obatolu. 1989. Soils and nutrition of cocoa, coffee, kola cashew and tea. Prog Tree Crop Res 2: 28-38.

Falade JA. 1978. Cashew growing soil in Nigeria. East Afr Agric J 43:100-105.

FAO [Food and Agriculture Organization]. 2010. Food and Agriculture Organization of the United Nations. h t t p : / f a os tat.fao.org/site/567/ DesktopDefault.aspx? PageID=567\#ancor. Accessed on 21 January 2010.

Ibiremo OS and O Fagbola. 2008. Effect of phosphorus fertilizer and arbuscular mycorhizal fungi inoculation on the growth of cashew seedlings in two soils in Nigeria. Nigerian J Soil Sci 18: 138146. 
Ipinmoroti RR, OSO Akanbi, MA Daniel, LAAdebowale, GAAdewoye, EA Makinde and CO Kayode. 2011. Potentials of NPK and organic fertilizers on growth performance of cashew (Anacardium occidentale L.) seedlings on degraded typic alfisol soils in Ibadan, Nigeria. J Agric Sci Tech 1: 876-881.

Ipinmoroti RR, PAikpokpodion and OSO Akanbi. 2009. Nutritional assessment of cocoa plots for soil fertility management on some cocoa farms in Nigeria. Proceedings of $16^{\text {th }}$ International Cocoa Research Conference Held at Grand Hyatt Hotel, Nusa Dua, Bali, Indonesia, pp 1481-1485.

Iremiren GO and AM Ekhomun. 2005. Effects of N fertilizer rates on the performance of maize-okra mixture in an acid sand soil of the Nigerian forest zone. Nigerian J Appl Sci 23: 11-14.

McKenzie RH. 2001. Micronutrient requirements of crops. Alberta Agriculture and Rural development http://www1.agric.gov.ab.ca/\$department/ deptdocs.nsf/all/agdex713. Acessed on 21 July 2011.

Nelson DW and LE Sommers. 1982. Organic carbon and soil extracts In: D L Sparks (ed). Methods of soil Analysis. Part 2- Chemical and microbiological properties. Agronomy Monograph No.9, $2^{\text {nd }}$
Edition. American Society of Agronomy, Soil Science Society of America, Madison, WI, USA, pp. 539-579.

Ogunlade MO, OS Ibiremo, RR Ipinmoroti, CI Iloyanomon and PE Aikpokpodion. 2011. Determination of phosphorus and potassium fixation capacities and fertilizer fctors in soils of three cocoa growing areas of Nigeria. J Soil Nat 5: 11-16.

Ogunmoyela OA and CR Obatolu. 1984. Nutrient studies and fertilizer requirements of Nigeria tea. Cafe Cacao The 28: 179-184.

Ogunwale JA, JO Olaniyan and MO Aduloju. 2002. Morphological, physico-chemical and clay mineralogical properties of soils overlaying basement complex rocks in Ilorin East, Nigeria. Moor J Agric Res 3: 147-154.

Ojeniyi SO. 1980. Nutrient studies of NPK treated coffee plots. Plant Soil 56: 175-179.

Omotoso TI. 1974. The effect of fertilizer and irrigation on the leaf macronutrient composition of Coffea canephora during a year. Turrialba 24: 315-318.

Opeke LK. 1987. Tropical tree crops. Spectrum Books Limited, Ibadan, Nigeria, p 247.

Wood GAR and RA Lass. 1985. Cocoa, $4^{\text {th }}$ ed. London: Longman, pp. 620-632. 